\title{
Presence of one ecto- and two endoparasite species of the black stork (Ciconia nigra) in Portugal
}

David W. Ramilo', Inês Caetano², Erica Brazio², Manuela Mira², Leonor Antunes³ ${ }^{3}$ Isabel Pereira da Fonseca ${ }^{1 *}$ and Luís Cardoso ${ }^{4}$

\begin{abstract}
Background: The black stork (Ciconia nigra Linnaeus, 1758) is a recognized endangered species in Europe and most of the specimens from the Western Palearctic region breed in the Iberian Peninsula. Available works regarding parasites in black storks are scarce. This work reports the presence one ecto- and two endoparasite species from a black stork in Portugal.

Case presentation: A black stork was found in southern Portugal after colliding against electric cables. The specimen did not survive its sustained injuries and a post-mortem exam was performed. During the procedure, several ecto- and endoparasite specimens were found. The collected parasites were lice (Neophilopterus tricolor), nematodes (Desportesius sagittatus) and trematodes (Cathaemasia hians).

Conclusions: Three different species of parasites are reported from a black stork in Portugal. Ecto- and endoparasites of $C$. nigra have not frequently been described in the literature, and this case report is a contribution to the field. Additional studies will be important to better understand the impact that parasites can have on $C$. nigra health and survival.
\end{abstract}

Keywords: Black stork, Cathaemasia, Desportesius, Neophilopterus, Portugal

\section{Background}

The black stork (Ciconia nigra Linnaeus, 1758) is a threatened species internationally protected and listed in Annex I of the EU Birds Directive [1]. This longdistance migratory bird has a wide territorial distribution, with more than $50 \%$ of their European population distributed across Eastern Europe [2-4]. On the other hand, this species is very rare in Western Europe, where it has suffered a drastic reduction due to the destruction of its natural habitat [5]. Among the black stork reproduction areas in Europe, western Spain, bordering

\footnotetext{
* Correspondence: ifonseca@fmv.ulisboa.pt

${ }^{1}$ CIISA - Centro de Investigação Interdisciplinar em Sanidade Animal, Faculdade de Medicina Veterinária, Universidade de Lisboa, Avenida da Universidade Técnica, 1300-477 Lisboa, Portugal

Full list of author information is available at the end of the article
}

Portugal, can be mentioned [5]. In mainland Portugal, this bird occurs inland, mainly along the hydrographic basins of Tagus, Douro and Guadiana rivers [6]. There are about 100 nesting couples in Portugal and some of these specimens are resident during the winter $[6,7]$. Usually, black storks migrate to Africa in the autumn, returning to Europe during the spring $[8,9]$.

Information concerning parasitological fauna found in C. nigra is available in a few published works, but data are still scarce and more studies are necessary [9-14]. The main reason for this lack of information is related to the black stork's habitat, since these birds breed in dense wood areas where precise nesting surveys are difficult to carry out. Moreover, because they are included in the list of protected animals in Europe [9], human

(C) The Author(s). 2021 Open Access This article is licensed under a Creative Commons Attribution 4.0 International License, which permits use, sharing, adaptation, distribution and reproduction in any medium or format, as long as you give appropriate credit to the original author(s) and the source, provide a link to the Creative Commons licence, and indicate if changes were made. The images or other third party material in this article are included in the article's Creative Commons licence, unless indicated otherwise in a credit line to the material. If material is not included in the article's Creative Commons licence and your intended use is not permitted by statutory regulation or exceeds the permitted use, you will need to obtain permission directly from the copyright holder. To view a copy of this licence, visit http://creativecommons.org/licenses/by/4.0/ The Creative Commons Public Domain Dedication waiver (http://creativecommons.org/publicdomain/zero/1.0/) applies to the data made available in this article, unless otherwise stated in a credit line to the data. 
Table 1 Measurements of male and female lice collected from Ciconia nigra

\begin{tabular}{|c|c|c|c|c|c|c|}
\hline \multirow{2}{*}{$\begin{array}{l}\text { Measurement } \\
(\mathrm{mm})\end{array}$} & \multicolumn{3}{|c|}{ Males $(n=10)$} & \multicolumn{3}{|c|}{ Females $(n=7)$} \\
\hline & Minimum & Maximum & Average & Minimum & Maximum & Average \\
\hline Cephalic length & 0.57 & 0.67 & 0.61 & 0.68 & 0.77 & 0.74 \\
\hline Cephalic width & 0.74 & 0.83 & 0.79 & 0.82 & 0.94 & 0.90 \\
\hline Thoracic length & 0.39 & 0.46 & 0.43 & 0.45 & 0.52 & 0.48 \\
\hline Thoracic width & 0.54 & 0.69 & 0.62 & 0.72 & 0.84 & 0.78 \\
\hline Abdominal length & 1.15 & 1.39 & 1.30 & 1.62 & 2.13 & 1.91 \\
\hline Abdominal width & 0.78 & 1.08 & 0.96 & 0.93 & 1.28 & 1.20 \\
\hline Total length & 2.11 & 2.52 & 2.34 & 2.75 & 3.42 & 3.13 \\
\hline
\end{tabular}

contact should be avoided in order to not disturb them in their natural habitat.

This report describes three different parasite species found in a black stork from Portugal.

\section{Case presentation}

An adult female black stork was found near Alqueva dam (38 $\left.11^{\prime} 51^{\prime \prime} \mathrm{N}, 7^{\circ} 29^{\prime} 47^{\prime \prime} \mathrm{W}\right)$, within the boundaries of the districts of Beja and Évora, southern Portugal, in March 2018, after colliding against electric cables. The specimen was received at the Wild Animal Rehabilitation Centre of Lisbon (LxCRAS) with several wounds, including an extensive hematoma in the pectoralis muscles, in the cranial zone of the keel and in the triceps muscle. After 3 days of treatment, the bird died due to the injuries and the corpse was sent to the Pathology Service of the Faculty of Veterinary Medicine of the University of Lisbon for post-mortem examination. During the procedure, trematodes that were present in the bird's mouth showed photophobic behaviour, moving back to the oesophagus when the beak was opened. Ectoparasites were collected in 70\% ethanol and later placed on slides with lactophenol or Canada balsam [15] and observed under light microscopy. Collected endoparasites were placed in a Petri dish containing saline solution before microscopic examination.

Adult stages of three different parasites were found: lice on breast and belly feathers $(n=26)$, nematodes in the gizzard $(n=2)$ and trematodes in the oesophagus $(n=27)$. For parasite species' identification, several

Table 2 Measurements of female nematodes collected from Ciconia nigra

\begin{tabular}{ll}
\hline Measurement $(\mathrm{mm})$ & Females $(n=2)$ \\
\hline Length & $6.12-6.36$ \\
Width & $0.219-0.252$ \\
Distance of vulva to the tip of the tail & 0.083 \\
Eggs (length $x$ width) & $0.03 \times 0.017$ \\
\hline
\end{tabular}

references were used $[9,10,12,16]$. Parasites measurements can be observed in Tables 1, 2 and 3 .

After preparation of lice by the Canada balsam technique, they were identified as Neophilopterus tricolor (Burmeister, 1838) (Fig. 1a and b), due to the presence of a fifth shorter marginal temporal seta when compared with the size of the other four setae. The performed measurements (Table 1) were in agreement with those registered for this species [10].

Following endoparasite observation, nematodes were recognized as Desportesius sagittatus (Rudolphi, 1809) (Fig. 2a and b). Desportesius sagittatus can be identified by length and morphology of the male right spicule and the greatly reduced deirids [16]. Since only two female specimens were found, the identification was made by this species' type host (i.e. C. nigra), the presence of reduced deirids and the performed measurements (Table 2), which matched those previously observed for this species [16, 17].

Trematodes were identified as Cathaemasia hians (Rudolphi, 1809) (Fig. 3a and b). The observed specimens had flattened body, presence of scales on the ventral cuticle and the head crown was lacking (Cathaemasiidae family). The obtained measurements were in agreement with those observed for this species (Table 3$)$. Eggs $(n=5)$ had a mean length of $98.3 \mu \mathrm{m}$ and an average width of $52.8 \mu \mathrm{m}$. These findings, together with the host and their localization, allowed species identification $[9,12,13,18,19]$.

Table 3 Measurements of trematodes collected from Ciconia nigra

\begin{tabular}{lccc}
\hline $\begin{array}{l}\text { Measurement } \\
(\mathrm{mm})\end{array}$ & \multicolumn{3}{l}{ Specimens $(n=10)$} \\
\cline { 2 - 4 } & Minimum & Maximum & Average \\
\hline Length & 5.76 & 7.20 & 6.50 \\
Width & 2.78 & 3.86 & 3.24 \\
Ventral sucker diameter & 9.16 & 15.48 & 11.84 \\
Oral sucker diameter & 6.84 & 8.95 & 8.09 \\
\hline
\end{tabular}



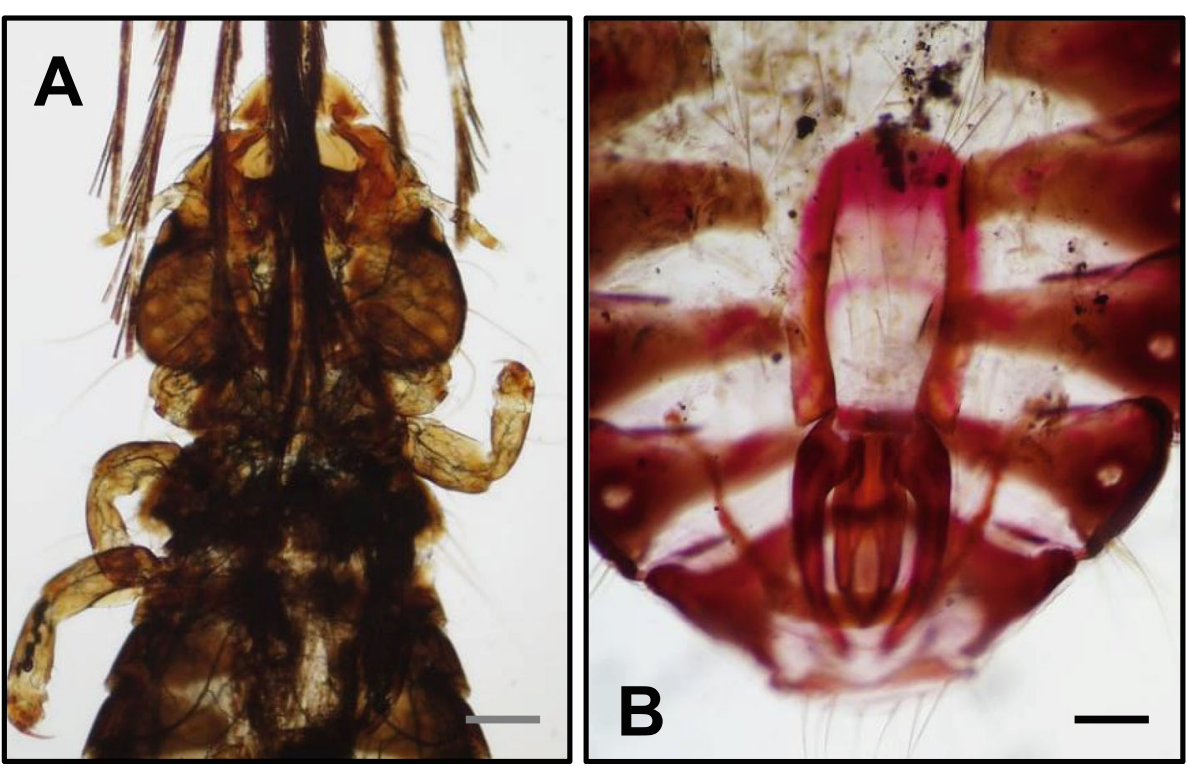

Fig. 1 Neophilopterus tricolor. a: head of female specimen (scale bar: $231.4 \mu \mathrm{m}$ ); b: abdomen of male specimen (scale bar: $210.8 \mu \mathrm{m}$ )

\section{Discussion and conclusions}

In the present work, three different parasites of C. nigra were observed during necropsy of an adult specimen. The genus Neophilopterus (Ischnocera: Philopteridae) has already been described in black storks from Spain [10]. Ischnocera lice can affect host thermoregulation and induce feather breakage, reducing host fitness through the energetic consequences of that damage. Stress is also an indirect effect to the affected host [10]. Lice specimens found in this report's black stork had four marginal temporal setae of approximately the same length but the last one was several times shorter, thus being identified as Neophilopterus tricolor. This is the first reference of this species in a black stork in Portugal. In what refers to nematodes, until the year 2015, only Austria, Czech Republic, Germany, Poland and Slovakia had information regarding helminth communities in storks [13]. The genus Desportesius (Nematoda: Acuarioidea) usually parasitizes birds of the order Ciconiiformes [17]. These nematodes occur under the gizzard lining [16], but nothing is known about their pathogenic effects on the hosts [14]. Desportesius sagittatus has also
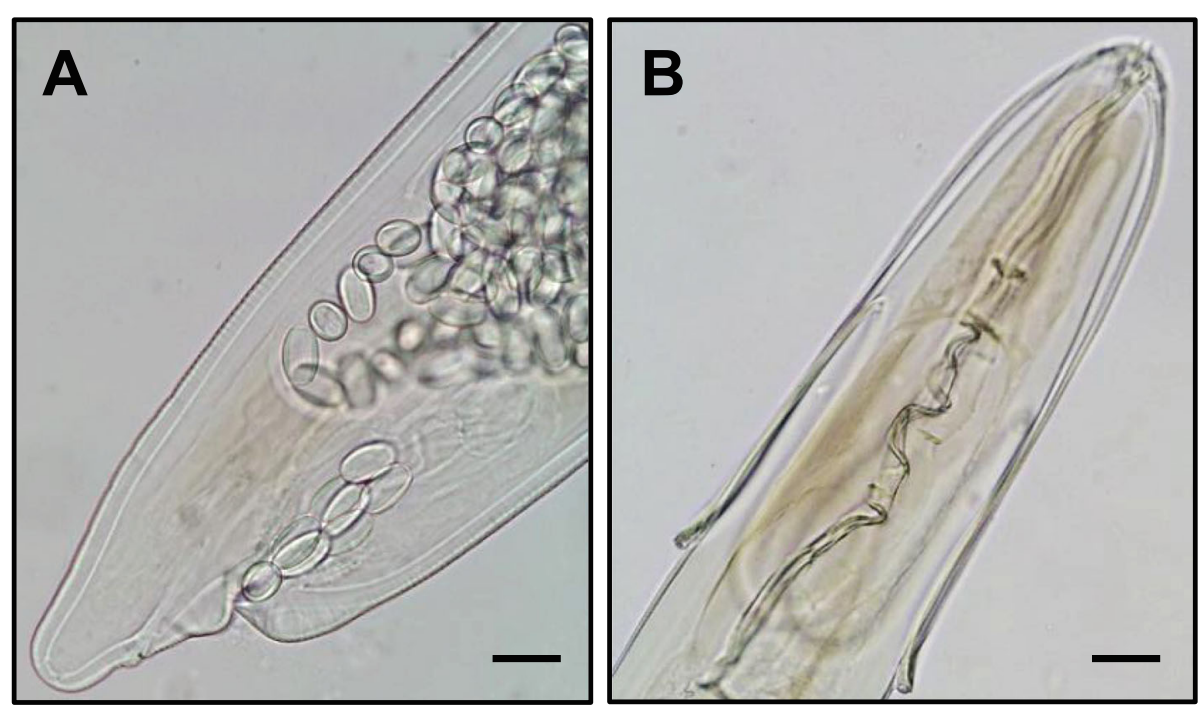

Fig. 2 Desportesius sagittatus female specimen. a: posterior end (scale bar: $34 \mu \mathrm{m}$ ); b: anterior end (scale bar: $67.4 \mu \mathrm{m}$ ) 

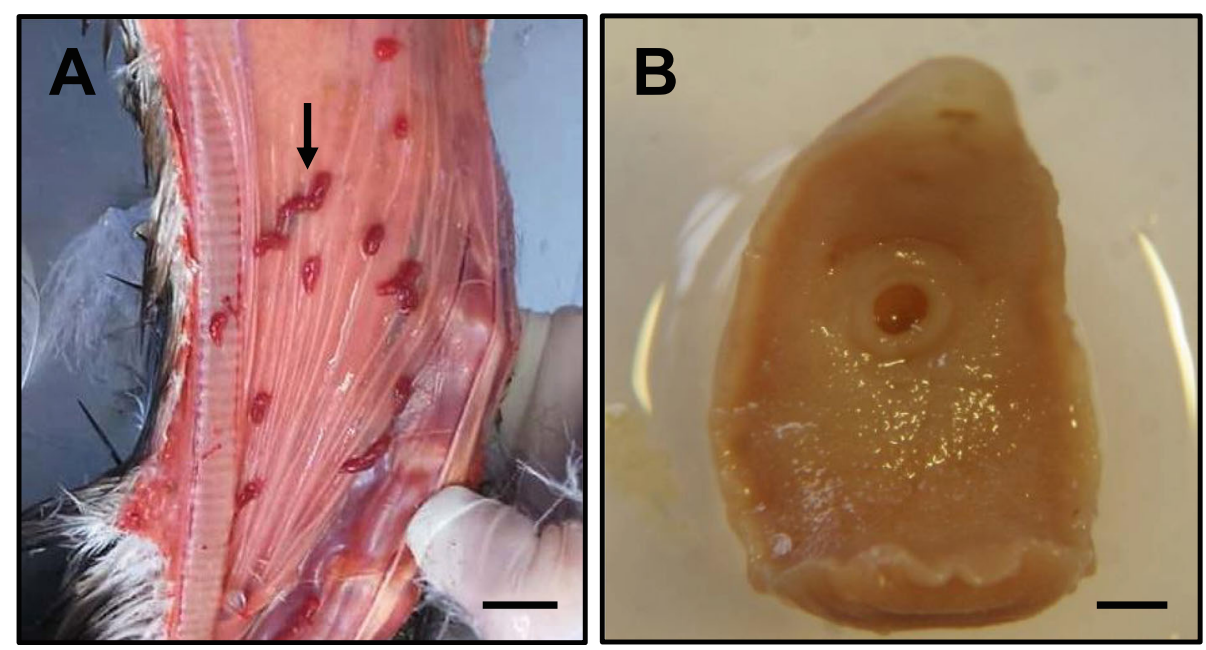

Fig. 3 Cathaemasia hians. a: Specimens (black arrow) on oesophagus (scale bar: $14.4 \mathrm{~mm}$ ); b: specimen ventral view (scale bar: $910 \mu \mathrm{m})$

been reported in C. nigra [13]. However, this is the first reference of this species in a black stork caught in mainland Portugal.

Considering trematodes, Cathaemasia hians (Trematoda: Cathaemasiidae) is a well-known species which has members of family Ciconiidae as definitive hosts and are generally found in the oral cavity and sometimes in the oesophagus of these birds. However, reports of this species in Europe have been rare [12]. Black storks are more likely to be infected with this parasite than white storks (Ciconia ciconia), due to their different feeding behaviour [18]. In fact, white storks feed on arthropods and earthworms from permanent dry pastures [20,21], and black storks ingest amphibians and fish parasitized with metacercariae of Cathaemasia hians, which live in swamps and slowflowing waters [12,18]. Cathaemasia hians is generally considered as non-pathogenic to storks [12, 13]. Nevertheless, this parasite can lead to irreversible alterations in the digestive tract of definitive hosts, lowering the birds' fitness. Massive infections by this parasite can cause serious health problems when combined with cachexia or lower immunity of the hosts $[9,13]$. This is also the first reference for this parasite in a black stork captured in Portugal.

Scientific studies regarding these birds are difficult to accomplish since they are hard to access and protected by European laws. Thus, living animals can only be found after sustaining serious injuries $[9,12,18]$, like in the present study.

Since parasitological works in C. nigra are scarce, this work is considered as an important contribution to this study field, reporting three parasite species in a black stork caught in mainland Portugal.

\section{Abbreviations}

C.: Ciconia ; EU: European Union; i.e.: id est, that is; LxCRAS: Wild Animal Rehabilitation Centre of Lisbon; mm: Milimeter; N: North; n: Sample size; W: West; $\mu \mathrm{m}$ : Micrometer

\section{Acknowledgements}

The authors would like to thank the Pathology Service of the Faculty of Veterinary Medicine, University of Lisbon, and students from the Integrated Master in Veterinary Medicine, who helped with the black stork necropsy, and to MSc André Tomás, who mounted the lice. DWR holds the FCT postdoctoral grant SFRH/BPD/115202/2016.

\section{Authors' contributions}

DWR conceptualized the study, identified the parasites and wrote the manuscript. IC, EB and MM clinically co-assisted the black stork and reviewed the manuscript. LA participated in laboratory work and reviewed the manuscript. IPdF and LC co-supervised the study and revised the manuscript. All authors read and approved the final manuscript.

\section{Funding}

This work was financed by national funds through FCT - Foundation for Science and Technology, I.P., within the scope of the project UIDB/00276/ 2020. This study was also funded by the project UIDB/CVT/00772/2020 supported by the Portuguese Science and Technology Foundation (FCT). Both funding bodies had no role in the design of the study and collection, analysis and interpretation of data and in writing the manuscript.

\section{Availability of data and materials}

The datasets used and/or analysed during the current study are available from the corresponding author on reasonable request.

\section{Ethics approval and consent to participate} Not applicable.

\section{Consent for publication}

Not applicable.

\section{Competing interests}

The authors declare that they have no competing interests.

\section{Author details}

${ }^{1}$ CIISA - Centro de Investigação Interdisciplinar em Sanidade Animal, Faculdade de Medicina Veterinária, Universidade de Lisboa, Avenida da Universidade Técnica, 1300-477 Lisboa, Portugal. ${ }^{2}$ LxCRAS - Wild Animal Rehabilitation Centre of Lisbon, Lisbon, Portugal. ${ }^{3}$ Student of the Integrated 
Master in Veterinary Medicine, Faculdade de Medicina Veterinária, Universidade de Lisboa, Avenida da Universidade Técnica, 1300-477 Lisboa, Portugal. ${ }^{4}$ Department of Veterinary Sciences, and Animal and Veterinary Research Centre (CECAV), University of Trás-os-Montes e Alto Douro (UTAD), Vila Real, Portugal.

Received: 13 February 2020 Accepted: 26 May 2020

Published online: 07 January 2021

\section{References}

1. Council of the European Communities.https://ec.europa.eu/environment/ nature/conservation/wildbirds/threatened/index_en.htm. Accessed 02 October 2019.

2. Strazds M. Conservation status of the Black stork in Europe and in the World. Aves. 2003:40:12-3.

3. Bobek M, Hampl R, Peske L, Pojer F, Somek J, Bures S. African Odyssey project - satellite tracking of black storks Ciconia nigra breeding at a migratory divide. J Avian Biol. 2008;39:500-6.

4. Chevallier D, Le Maho Y, Brossault P, Baillon F, Massemin S. The use of stopover sites by Black Storks (Ciconia nigra) migrating between West Europe and West Africa as revealed by satellite telemetry. J Ornithol. 2011; 152:1-13.

5. Lamanna F. Nesting of the Black Stork Ciconia nigra Linnaeus, 1758 (Aves Ciconiidae) in the Fiumara Vitravo Valley (Calabria, Italy). Biodivers J. 2016;7: 3-6.

6. Almeida J, Catry P, Encarnação V, Franco C, Granadeiro JP, Lopes R, et al. Ciconia nigra Cegonha-preta. In: Cabral MJ et al, editors. Livro Vermelho dos Vertebrados de Portugal. Lisboa: Instituto da Conservação da Natureza; 2005. pp. 179-80.

7. Cano LS. An approach to wintering of black stork Ciconia nigra in the Iberian Peninsula. Biota. 2006;7:7-13

8. Cano LS, Franco C, Doval G, Torés A, Carbonell I, Tellería JL. Post-breeding movements of Iberian Black Storks Ciconia nigra as revealed by satellite tracking. Ardeola. 2013;60:133-42

9. Königová A, Hrčková G, Molnár L, Major P, Várady M. Cathaemasia hians in Black stork in Slovakia: morphological and histopathological study. Helminthologia. 2015:52:316-22.

10. Lanzarot MP, Martín-Mateo MP, Merino S, Fernández-Garcia M. A redescription of Neophilopterus tricolor (Burnmeister, 1838) (Insecta: Phtiraptera: Ischnocera: Philopteridae) from the black stork Ciconia nigra (L.) (Aves) with notes on its prevalence. J Nat Hist. 2005;39:3471-80.

11. Błoszky J, Gwiazdowicz DJ, Halliday B, Dolata PT, Gołdyn B. Nests of the black stork Ciconia nigra as a habitat for mesostigmatid mites (Acari: Mesostigmata). Biologia. 2009;64:962-8.

12. Liptovszky M, Majoros G, Perge E. Cathaemasia hians in a Black Stork (Ciconia nigra) in Hungary. J Wildl Dis. 2012:48:809-11.

13. Sitko J, Heneberg P. Composition, structure and pattern of helminth assemblages associated with central European storks (Ciconiidae). Parasitol Int. 2015;64:130-4

14. Tomás A, Rebelo MT, Pereira da Fonseca I. Occurrence of helminth parasites in the gastrointestinal tract of wild birds from Wildlife Rehabilitation and Investigation Centre of Ria Formosa in southern Portugal. Vet Parasitol. 2016;8:13-20

15. Palma RL. Slice-mounting of lice: a detailed description of the Canada Balsam technique. NZ Entomol. 1978;6:432-6.

16. Wong PL, Anderson RC. Revision of the genus Desportesius Chabaud and Campana, 1949 (Nematoda: Acuarioidea) mainly from the gizzard of ciconiform birds. Can J Zool. 1986;64:2520-30.

17. Baruš V, Sergeeva TP, Sonin MD, Ryzhikov KM. Genus Despotesius Skrjabin, Sobolev \& Ivashk, 1965. In: Rysavy B, Ryzhikov KM, editors. Helminths of fisheating birds of the Palaearctic Region I: Nematoda. Dordrecht: Springer; 1978. pp. 135-43.

18. Merino S, Martinez J, Lanzarot P, Cano LS, Fernandez-Garcia M, RodriguezCaabeiro F. Cathaemasia hians (Trematoda: Cathaemasiidae) infecting black stork nestlings (Ciconia nigra) from central Spain. Avian Pathol. 2001;30:55961.

19. Van Den Broek E. Considerations on the taxonomy of the genus Cathaemasia. Arch Neerl Zool. 1963;15:472-90.

20. Alonso JC, Alonso JA, Carrascal LM. Habitat selection by foraging white storks, Ciconia ciconia, during the breeding season. Can J Zoology. 199169: 1957-62.
21. Carrascal LM, Bautista LM, Lázaro E. Geographical variation in the density of white stork Ciconia ciconia in Spain: influence of habitat structure and climate. Biol Conserv. 1993;65:83-7.

\section{Publisher's Note}

Springer Nature remains neutral with regard to jurisdictional claims in published maps and institutional affiliations.

\section{Ready to submit your research? Choose BMC and benefit from:}

- fast, convenient online submission

- thorough peer review by experienced researchers in your field

- rapid publication on acceptance

- support for research data, including large and complex data types

- gold Open Access which fosters wider collaboration and increased citations

- maximum visibility for your research: over $100 \mathrm{M}$ website views per year

At $\mathrm{BMC}$, research is always in progress.

Learn more biomedcentral.com/submissions 